Henrik Hagemann

\title{
En nordisk indsats
}

Om Nordisk Råds fornemme indsats til støtte for de baltiske landes løsrivelse fra Sovjetunionen og begyndelsen på det nuværende $\varnothing$ stersøsamarbejde - et personligt tilbageblik med glimt bag kulisserne. 


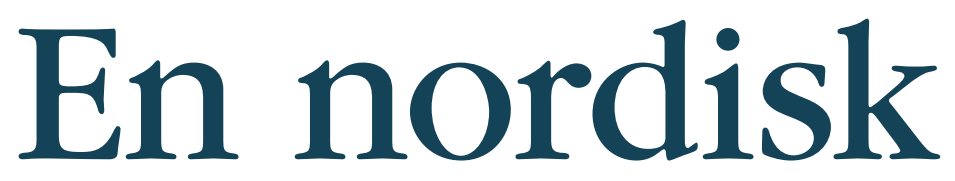

indsats

Om Nordisk Råds fornemme indsats til støtte for de baltiske landes løsrivelse fra Sovjetunionen og begyndelsen på det nuværende Østersøsamarbejde - et personligt tilbageblik med glimt bag kulisserne. 


\section{En nordisk indsats}

Henrik Hagemann

US 2014:402

ISBN 978-92-893-2719-0

DOI http://dx.doi.org/10.6027/US2014-402

(C) Nordisk Råd, København 2014

Tryk: Rosendahls - Schultz Grafisk

Layout: Erling Lynder

Oplag: 700

Trykt på miljøvenlgt papir

Printed in Denmark

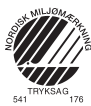

Baltic Sea Parliamentary Conference www.bspc.net

\section{Jan Widberg}

Generalsekreterare

jw@norden.org

\section{BSPC Sekretariat}

c/o Nordisk Råd

Ved Stranden 18

1061 København K.

Telefon (+45) 33960400

www.norden.org.
Den Parlamentariske Østersøkonference (BSPC) blev etableret i $1991 \mathrm{og}$ er et forum for politisk dialog mellem parlamentarikere

i Østersøregionen. BSPC har til formål at skabe opmærksomhed om og være meningsdannende i forhold til aktuelle og relevante politiske problemstillinger i Østersøregionen. BSPC

skal fremme og fungere som drivkraft forforskellige initiativer og indsatser med henblik på at støtte en miljømæssigt, socialt og økonomisk bæredygtig udvikling i $\varnothing$ sters $\emptyset$ regionen. BSPC arbejder for at øge kendskabet til Østersøregionenog problemstillingerne $\mathrm{i}$ områdeti en bredere europæisk kontekst.

BSPC består af parlamentarikere fra 11 nationale parlamenter, 11 regionale parlamenter samt 5 parlamentariske organisationer i Østersøregionen. BSPC udgør således en unik parlamentarisk bro mellem alle lande både $\mathrm{i}$ og uden for EU i $\emptyset$ stersøregionen.

BSPC har blandt andet eksterne berøringsflader med regeringsorganisationer, parlamentarikerorganisationer, subregionale og andre organisationer i Østersøregionen og Den Nordlige Dimensions område, herunder CBSS, HELCOM, partnerskabet for folkesundhed og social velfærd inden for den nordlige dimension (NDPHS), Baltic Sea Labour Forum (BSLF), $\varnothing$ sters $\varnothing$ landenes Subregionale Samarbejde (BSSSC) og Baltic Development Forum.

BSPC skal varetage en initierende og rådgivende funktion i forhold til politiske aktiviteter i regionen; fremme og styrke de demokratiske institutioner i deltagerlandene; forbedre dialogen mellem regeringer, parlamenter og civilsamfund; styrke Østersøregionens fælles identitet ved hjælp af et tæet samarbejde mellem nationale og regionale parlamenter baseret på ligestilling; samt bidrage til at styrke den demokratiske legitimitet blandt forskellige politiske aktiviteter i Østersøregionen.

De politiske anbefalinger fra de årlige parlamentariske konferencer formuleres i en konsensusresolution, som godkendes af konferencen. Den godkendte resolution sendes til regeringerne i Østersølandene, til CBSS og til EU. Desuden sendes den til andre relevante nationale, regionale og lokale interessenter $\mathrm{i}$ Østersøregionen og de nærliggende lande. 


\section{Indhold}

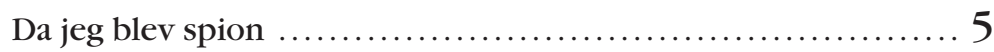

Da Nordisk Råd åbnede sig mod omverdenen ................ 7

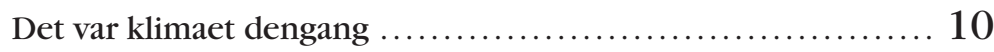

Nye tider, nye brydninger .......................... 10

Sådan løser man et dilemma ............................ 16

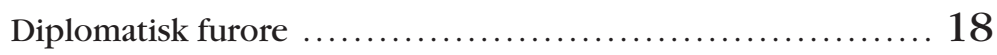

Hvad kom denne session til at betyde for de baltiske gæster? .. 20

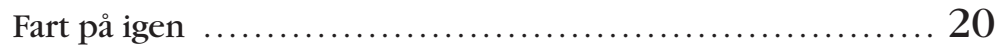

Baltisk Forsamling og Baltisk Råd ....................... 23

De parlamentariske Østersøkonferencer og regeringernes Østersøråd ......................................... 24

Regeringerne klar til udrykning ...................... 24

Nordisk Råd og det parlamentariske Østersøsamarbejde ....... 25

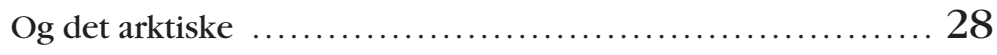

Hvad bliver det næeste? ............................... 30

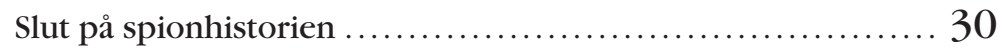

Afsluttende uvidenskabelig efterskrift $\ldots \ldots \ldots \ldots \ldots \ldots \ldots \ldots \ldots \ldots \ldots$ 



\section{En nordisk indsats}

I årene fra 1986 og frem til midten af 1990erne ydede parlamentarikerne i Nordisk Råd en indsats af international historisk betydning - hverken mere eller mindre. Regeringerne kunne kun i begrænset omfang støtte løsrivelsesbevægelserne i de baltiske lande. Dertil var frygten for en sovjetisk modreaktion af gode grunde alt for stor; tænk bare på Ungarn 1956 eller Tjekkoslovakiet 1968.

Men parlamentarikerne i Nordisk Råd kom med deres indsats både til at give legitimitet til løsrivelsesbevægelserne i de baltiske lande og til at skabe jordbund for de nordiske regeringers indsats efter at Rusland havde accepteret løsrivelsen i august 1991.

Nordisk Råd er et enestående mellemstatsligt samarbejdsorgan og brydningssted. Her mødes ministre og parlamentarikere på tværs af parti- og landegrænser i et fælles forum for at drøfte aktuelle politiske problemer og for at søge fælles optræden i en række spørgsmål. Det nordiske samarbejde anses internationalt for noget af det mest uformelle som officielt samarbejde betragtet; men det officielle samarbejde har mindst lige så stor betydning som ramme om et tæet sammenflettet netværkssamarbejde i Norden.

Det nordiske samarbejde er et netværkssamarbejde mere end noget andet. Og i netværk foregår der rigtig meget uden for de officielle protokoller og referater. Hensigten med dette skrift er derfor at en af dem der var tættest på parlamentarikernes arbejde i 1980erne og 1990erne, fortæller og inddrager elementer som af gode grunde ikke tidligere har været offentliggjort - også om stormagternes interesse for arbejdet. ${ }^{1}$

\section{Da jeg blev spion}

At Sovjetunionen og derefter Rusland interesserede sig meget for Nordisk Råds arbejde, det kom bag på mig. Kort efter at jeg i 1984 var tiltrådt som generalsekretær for Danmarks Riges Delegation til Nordisk Råd, fik jeg en telefonopringning fra den sovjetiske ambassade med en forespørgsel om ambassadesekretær "Sergei ..." måtte aflægge mig et besøg. Jeg tog lige en gang i bordkanten og tænkte ved mig selv hvad pokker det nu var for en stilling jeg havde fået. Og jeg tænkte straks på Treholt-affæeren i Norge der var på sit højeste på det tidspunkt. Norge havde i mange år haft

1 Nordisk Råds og i nogen udstrækning regeringernes arbejde med forholdet til de baltiske lande er beskrevet i "50 år til nordisk nytte? - Nordisk Råd 1952-2002" udgivet af Nordisk Råd 2002, især s. 105-116 (Øyvind Tønnesson, historiker), s. 183-185 (Elsi Hetemäki-Olander, tidl. vicetalman i Finlands riksdag) og s. 200-201 (Karin Söder, fhv. udenrigsminister). 
en alvorlig uenighed med Sovjet om græensedragningen i Barentshavet og dermed om bl.a. fiskerettigheder. Arne Treholt var en betroet medarbejder i det norske udenrigsministerium som havde udleveret oplysninger om de norske forhandlingspositioner til Sovjet. Han fik i 1985 en dom på 20 års fængsel for spionage. Den sag kørte således i efteråret 1984. Heldigvis spurgte jeg i samtalen med ambassaden om jeg måtte ringe tilbage. Og så skyndte jeg mig at ringe til vores daværende fortræffelige bureauchef, som det hed dengang, i Folketinget, Helge Hjortdal. Han havde været kontorchef i Statsministeriet under H.C. Hansen, Kampmann og Krag og bl.a. været involveret i forbindelse med de sovjetiske transporter til Cuba gennem danske farvande i sin tid, så han vidste hvad det drejede sig om. Han var en rigtig pater familias - og havde format til det. Da jeg havde forelagt problemet, sagde han: "Du må endelig tage imod ham, Henrik. Du må endelig tage imod ham. Han skal jo skrive indberetninger hjem til Moskva, og hvis ikke du fortæller ham hvad der foregår i det nordiske, skriver han bare hvad der står i Land og Folk. ${ }^{2}$ Og det kan vi jo ikke have." Så jeg ringede tilbage til ambassaden og aftalte en tid for en samtale - på mit kontor. Og orienterede Udenrigsministeriet.

Sergei ... kom, og det gjorde han ca. hvert kvartal i mere end 10 år afløst af kolleger gennem årene, af andre Sergei'er. De var alle meget dygtige og talte fremragende dansk. Jeg havde fået det man i Finland kaldte en "husryss", erfarede jeg snart; i Finland fik politikere og embedsmænd af en vis tyngde i alle årene under den kolde krig besøg af en medarbejder fra den sovjetiske ambassade. Jeg orienterede på passende vis, syntes jeg selv dengang, min "husryss" om alt det vi havde gang i med Norden som atomvåbenfri zone, miljøpolitik, støtte til de baltiske lande, opvarmning til en ny Østersøpolitik osv. Det skal jeg fortælle lidt om til forståelse af en tid og en atmosfære som allerede er os meget fjern nu. Men har været helt afgørende for hvordan vi har det i dag.

\section{Da Nordisk Råd åbnede sig mod omverdenen}

Der skete virkelig noget nyt i Nordisk Råds arbejde i 1986 og de nærmest følgende år. Man skal huske at det officielle nordiske samarbejde er udenrigs- og sikkerhedspolitik, og at forholdet mellem de nordiske lande har været bestemt af de rammebetingelser som forholdet mellem stormagterne har sat - altid, uanset hvad min generation har lært af nationalistisk sludder i historietimerne i skolen i sin tid. 
Da Nordisk Råd blev oprettet i 1952, turde man ikke indgå en formel konvention eller traktat, men valgte at etablere Rådet ved at vedtage enslydende love i hvert af landene; det er jo lettere at ændre en lov end at opsige en mellemstatslig aftale. Finland måtte slet ikke være med i første omgang, for Stalin anså Nordisk Råd for at være et Nato-projekt. Og den norske regering havde bedt om at udenrigspolitik ikke skulle indgå i rådets arbejdsområder. Derfor indgik udenrigspolitik ikke i bestemmelserne for rådets virke. ${ }^{3}$

Da Finland fik mulighed for at blive medlem af Nordisk Råd i 1955, skete det desuden med udtrykkelig finsk tilkendegivelse af at hvis Nordisk Råd ville beskæftige sig med sager som vedrørte forholdet mellem stormagterne, ville den finske delegation ikke deltage $i$ behandlingen. Det betød reelt at nok kunne man drøfte udenrigs- og sikkerhedspolitiske spørgsmål i generaldebatterne, og det gjorde man, men en egentlig sagsbehandling med beslutningsforslag, udvalgsbehandling, betænkninger og afstemninger var tabu - og er det i nogen udstrækning stadig.

\section{1984 var den kolde krig fortsat meget kold. Sovjetunionen var} stivnet i doktrinær bolsjevisme. Andropov havde afløst Bresjnev i 1982; Andropov var ganske vist en gammel apparatjik med stærk centralisme, men han havde samtidig sat en proces i gang for at forny kommunistpartiet og gøre op med korruptionen, en proces som Gorbatjov så videreførte med sin glasnost (et ord som er på retur nu, = åbenhed) og perestrojka (= reformprogram); begge ord har i Den Danske Ordbog betegnelsen "nu sj." - det kunne det sovjetiske kommunistparti ikke holde til i længden.

I Vesteuropa var der op til midten af 1980erne en stilfærdig udvikling. EF flyttede sig ikke ret meget, og det nordiske samarbejde gjorde heller ikke, eftersom Finland følte sig låst af den såkaldte venskabs-, samarbejds- og bistandstraktat som Sovjet havde påtvunget Finland ved fredsslutningen efter 2. verdenskrig. Norden var temmelig delt: Finland låst af Sovjet (man måtte ikke engang være medlem af Europarådet), Sverige holdt sig alliancefrit, Danmark, Norge og Island var medlemmer af Nato, Island på den måde at man ikke selv havde noget militær men havde stillet Keflavíkbasen til rådighed for Nato - og Danmark var det eneste nordiske land der var medlem af EF.

Hvor svært det var at manøvrere viser to begivenheder: I begyndelsen af 1985 indbød Anker Jørgensen til en nordisk parlamentarikerkonference som skulle afholdes i november på Christiansborg, om Norden som atomvåbenfri zone. Jeg bistod ham 


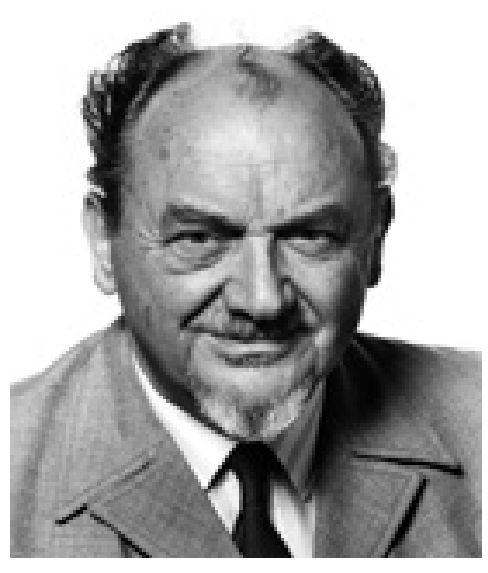

Fhv. statsminister Anker Jørgensen fotograferet sidst i 1980erne.

F. 1922. Danmarks statsminister 1972-73 og 1975-82. Nordisk Råds prasident 1986 og 1991. Billedet er velvilligst stillet til rådighed af Arbejderbevagelsens Bibliotek og Arkiv.

lidt med forberedelserne, og på et tidligt tidspunkt spurgte jeg ham om ikke vi skulle arrangere konferencen i Nordisk Råds regi, for så ville vi have et stærkere administrativt apparat til rådighed. Kun en konference, ikke noget med at bruge Nordisk Råds formelle instrumenter i form af rekommandationer eller formelle spørgsmål til regeringerne.

Temaet var væesentligt i den sikkerhedspolitiske debat. Olof Palme var en stærk fortaler for Norden som atomvåbenfri zone, Gro Harlem Brundtland var blevet forsigtig tilhænger, de danske socialdemokrater var blevet tilhængere efter 1982, og Finlands Kalevi Sorsa var en stærk tilhænger fordi Finland så Norden som atomvåbenfri zone som et middel til at forhindre Sovjet i i givet fald at kræve opstilling af sovjetiske atomvåben på finsk jord med henvisning til venskabs-, samarbejds- og bistandstraktaten.

Anker Jørgensen tænkte sig grundigt om før han svarede på mit spørgsmål om hvorvidt vi skulle arrangere konferencen i Nordisk Råd-regi, eller om han skulle holde den i sit partiapparat. Han sagde at det ville være alt for risikabelt at placere konferencen i Nordisk Råd-regi - så følsom var den storpolitiske situation.

Den anden begivenhed: I dagene 8.-10. september 1986 var Nordisk Råd vært for første gang for en stor international parlamentarikerkonference, den første nogensinde om grænseoverskridende luftforurening. Den foregik i det alliancefri Sveriges riksdag. Der var repræsentanter for parlamenter på begge sider af jerntæppet: Belgien, Frankrig, Holland, Polen, Schweiz, Sovjetunionen, Storbritannien, Tjekkoslovakiet, Den Tyske Demokratiske Republik, Forbundsrepublikken Tyskland, Østrig, Danmark, Finland, Island, Norge og Sverige, og for flere internationale organisationer: De Forenede Nationers Økonomiske Kommission for Europa (ECE), Europa-Parlamentet, Europarådet, De Europæiske Fællesskaber (EF), Den Europæiske Frihandelsorganisation (EFTA), Organisatio- 


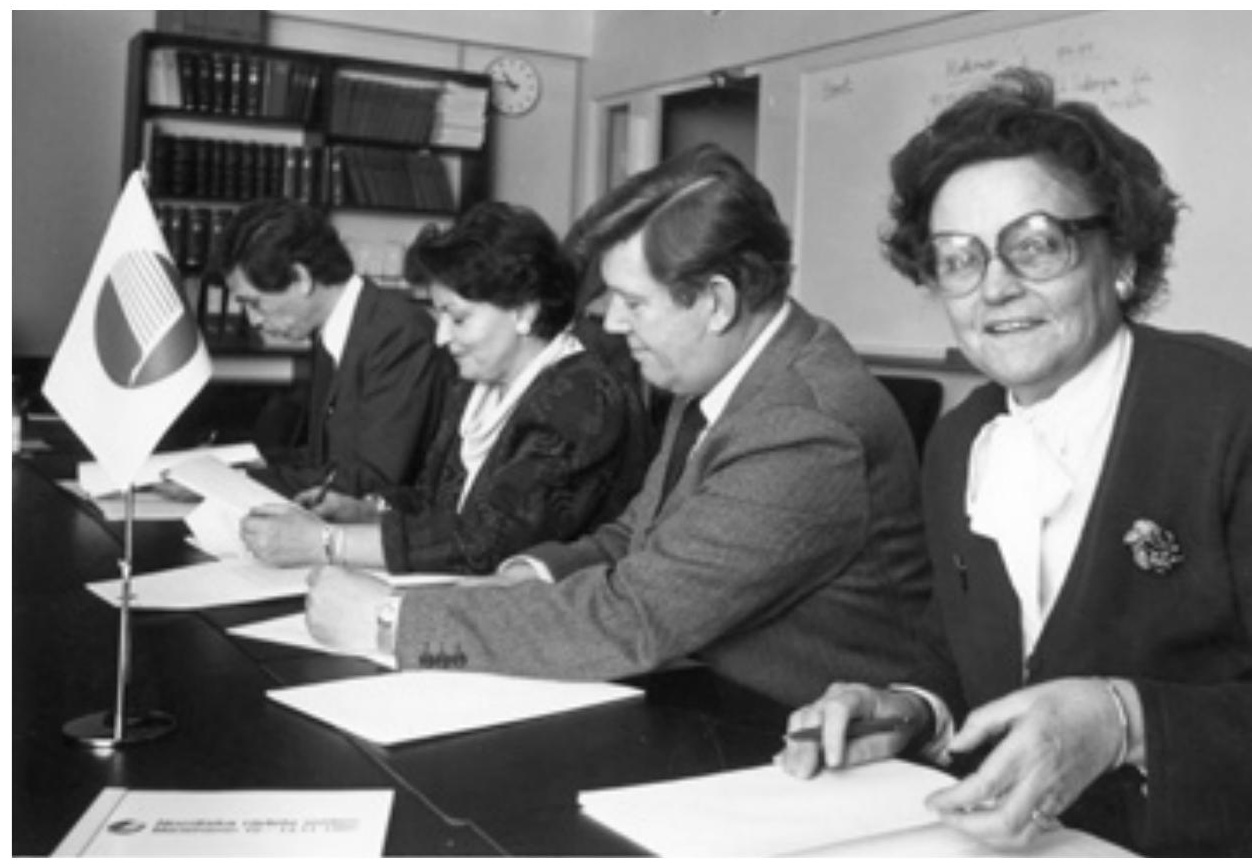

Nordisk Råds Proesidium 1986. Fra venstre: Hallvard Bakke (Ap), Norge, minister 1976-79 og 1986-89, medlem af Nordisk Råds Prasidium 1985-86; Elsi Hetemäki-Olander (Kok), Finland, Finlands riksdags 1. vicetalman 1987-91, Nordisk Råds prcesident 1982 og 1987; Páll Pétursson (F), Island, minister 1995-2003, Nordisk Råds praesident 1985 og 1990; Karin Söder (c), Sverige, udenrigsminister 1976-78, socialminister 1979-82, Nordisk Råds prasident 1984 og 1989. På billedet mangler Anker Jørgensen. Billedet tilhører Nordisk Råd.

nen for Økonomisk Samarbejde og Udvikling (OECD), Rådet for Gensidig Økonomisk Bistand (Comecon), Den Meteorologiske Verdensorganisation (WMO) og De Forenede Nationers Miljøprogram (UNEF).

Der skulle behandles et forslag til konsensusdokument som kunne følges op hjemme over for regeringerne. Forhandlingen om den endelige udformning af slutdokumentet foregik i en gruppe med en repræesentant for hvert af de deltagende parlamenter og for de deltagende organisationer under ledelse af Karin Söder; hun var tidligere udenrigsminister i Sverige og højt respekteret - Nordens første kvindelige partileder. Fra dansk side var Dorte Bennedsen med i arbejdsgruppen, og samspillet mellem hende og Karin Söder var naturligvis fint, de kendte hinanden særdeles godt. Det undrede virkelig repræsentanterne fra østlandene at folk fra to forskellige lande og partier kunne spille sådan sammen. Forhandlingerne gik meget tungt på første- og andendagen. Det hyppigste ord fra polakken, bal- 
terne, østtyskeren og tjekken var njet; sovjetrepræsentanten sagde ikke ret meget. Om aftenen efter andendagen var vi spændte på om dette her kunne føre til noget som helst. Næste morgen var tonen i forhandlingen en helt anden. Sovjetrepræsentanten overtog forhandlingen for østlandene, og i løbet af få timer var et udmærket slutdokument vedtaget. Det viste sig at blive et nyttigt værktøj som støttede de nordiske regeringers bestræbelser på enighed i Europa om fælles foranstaltninger mod miljøskader.

Ved afslutningsfrokosten skulle den sovjetiske delegationsformand sige tak for mad og afrunde konferencen. Han sagde rent ud at Nordisk Råd efter hans vurdering var den eneste instans der havde kunnet arrangere en sådan konference og oven i købet få den gennemført med succes.

\section{Det var klimaet dengang}

Den slags var min styringsagent, som jeg omtalte Sergei ... som, naturligvis interesseret i. Og han var da så venlig at han hvert år til nytår sendte mig en flaske Stolichnaya og et glas ægte kaviar. Det varede dog ikke så længe: Jeg tror det var i 1988 vi i Danmark havde en skandale med noget bestikkelse af embedsmænd i Helsingør Kommune. Stor ballade. Ninn-Hansen var justitsminister og proklamerede at embedsmænd efter hans opfattelse overhovedet ikke måtte modtage noget som helst. Da så Sergei ... kom næste gang, spurgte jeg ham om ikke han ville slette mig af deres liste med nytårshilsener, altså vodkaen og kaviaren. Han var da stadig velkommen så jeg kunne fortælle ham om noget af det vi foretog os. Svaret trak han på og var ikke villig til at imødekomme mit ønske. Da jeg pressede på, sagde han at det kunne han virkelig ikke forstå, for de plejede da at sende hvert år til både statsministeren og justitsministeren.

\section{Nye tider, nye brydninger}

I 1985-86 begyndte et nybrud i nordisk og europæisk politik. EFKommissions-formanden Jacques Delors' hvidbog førte til den såkaldte Single Act (det indre marked) som Danmark tilsluttede sig efter en vejledende folkeafstemning i 1986. Det satte ny fart i EF.

Gorbatjov holdt en vigtig tale i Murmansk i oktober 1987 hvori han bl.a. accepterede Finland som neutralt land og ikke længere som en de facto-del af den sovjetiske interessesfære. Det løsnede gevaldigt op for spæendingen mellem øst og vest her hos os i det nordlige Europa.

Men Finland var alligevel fortsat meget, meget forsigtig i forhold til den store nabo mod øst. Den 26. april 1986 indtraf ulykken på atom- 
kraftværket i Tjernobyl. Den radioaktive sky fra ulykken gav nedfald helt op i det sydlige Finland og det mellemste Sverige og Norge. I Finland blev man tidligt opmærksom på hvad der var sket, men i sin forsigtighed var man mere end to dage om at give et varsel videre til de andre nordiske lande. Ved et møde mellem Nordisk Råds Præesidium og de nordiske samarbejdsministre i maj 1986 blev den finske minister Gustav Björkstrand kritiseret i meget skarpe vendinger af Rådets præsident Anker Jørgensen for Finlands tilbageholdenhed.

Ved Nordisk Råds session i København i 1986 behandlede man et forslag til rekommandation, dvs. en formel henstilling til regeringerne, om noget så diskret som nordisk samarbejde i international sammenhæng.

Forslagsstillerne i 1986 var Finlands tidligere udenrigsminister Pär Stenbäck, Arbeiderpartiet i Norges politiske ordfører i Stortinget Reiulf Steen, moderaternas (de konservative i Sverige) Ingrid Sundberg, det islandske Fremskridtspartiets Páll Pétursson (svarer til det danske Venstre) og Anker Jørgensen.

Sessionen i marts 1986 var den første jeg var administrativ chef for. Tre dage inden blev Olof Palme myrdet. Det kom naturligvis til at præge hele forløbet. Det var hårdt arbejde og en følelsesmæssig belastning også for os medarbejdere i Nordisk Råd og i Folketinget. Men det er en anden historie.

På den baggrund blev behandlingen af forslaget til rekommandation om nordisk samarbejde i international sammenhæng meget afdæmpet, og regeringerne ville ikke melde klart ud. De tilkendegav dog at de ikke ville være med til en fælles international samarbejdskomite med repræsentanter fra både regerings- og parlamentarikersiden. Regeringerne tilbød at lade en embedsmandsgruppe vurdere det internationale samarbejde. Den samme holdning som altid at udenrigspolitik er for farligt og vanskeligt til at parlamentarikere skal have lov til at blande sig. Det var ikke tilfredsstillende for flertallet i Nordisk Råd. Dengang turde man sige regeringerne imod. Sagen blev derfor udsat. Og i tiden indtil sessionen 1987 i Helsingfors arbejdede både Nordisk Råds Præsidium og Nordisk Råds Økonomiske Udvalg grundigt med sagen.

Let var det ikke, for man kunne jo frygte tilbageslag fra den begyndende åbenhed i Sovjetunionen, men hvordan skulle man balancere mellem forsigtighed og fejhed?

Også Folketinget drøftede sagen. Under en forespørgselsdebat i december 1986 om samarbejdet mellem de europæiske stater sagde 


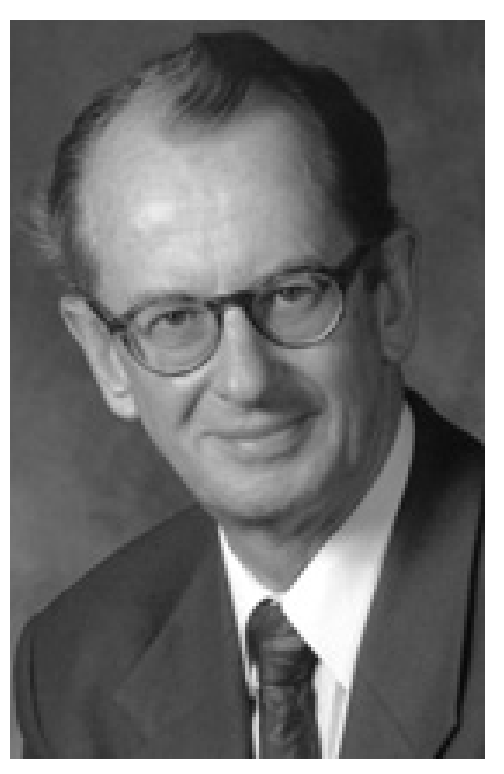

Fhv. statsminister Jan P. Syse fotograferet sidst i 1980erne. F. 1930, d. 1997. Norges statsminister 1989-90. Nordisk Råds prcesident 1988 og 1993. Billedet er velvilligst stillet til rådighed af Stortingsarkivet/ Scanpix.

udenrigsminister Uffe Ellemann-Jensen at den danske regering ikke ønskede at deltage i Den Europæiske Fælles Akt (det indre marked) uden at have forvisning om at det kunne ske uden at mindske muligheden for at videreføre det nordiske udenrigspolitiske samarbejde.

Ved sessionen året efter i Helsingfors var tonen en ganske anden. Debatten var skarp. De Konservative anført af Norges tidligere statsminister Jan P. Syse og stort set hele den finske delegation var voldsomt imod. De konservative ønskede ikke at Nordisk Råd skulle arbejde med egentlig udenrigspolitik og dermed give plads for EF-skeptikere der havde svært ved at slå igennem med deres synspunkter nationalt. Og de finske medlemmer var bekymrede for Finlands forhold til Sovjet. Det gik endda så vidt ved den session at Mauno Koivisto, republikkens præsident, ved sin fine frokost for Nordisk Råds Præesidium, statsministrene og enkelte andre, holdt en forbløffende ironisk tale hvori han sammenlignede Nordisk Råds session med en cirkusforestilling og derfor anså Nordisk Råd som komplet uegnet som forum for en egentlig behandling af udenrigspolitiske spørgsmål. Hans gamle ven og partifælle Anker Jørgensen sad ved siden af som Nordisk Råds præsident og kunne naturligvis ikke tage til genmæle. Jeg har ikke hverken før eller siden oplevet noget lignende i internationalt samarbejde. Og fem år efter ved den tilsvarende frokost havde balterne så fået deres selvstændighed - og Anker Jørgensen fået ret. Nu blev han modtaget meget hjerteligt af den samme præsident Koivisto. Til forståelse af præsident Koivisto hører det imidlertid med at han som ansvarlig for Finlands udenrigspolitik og dermed for balancegangen i forhold til Sovjetunionen måtte føre 
en meget stabil og fast kurs. I forbindelse med hans 90 års fødselsdag i november 2013 er det blevet oplyst at han i virkeligheden sad på to stole i spørgsmålet om de baltiske landes frigørelse fra Sovjet. Han benyttede kulturforeningen "Tuglas-sällskapet" til sin støtte. Esterne siger selv at den støtte var af afgørende betydning, og at man vel forstår hans dilemma. Koivisto skal selv have kommenteret det på sin typiske facon med at "kulturen kan anvendes til meget". ${ }^{4}$

Debatten i Helsingfors førte dog til at Nordisk Råds Præsidium nedsatte en kompetent parlamentarikerkomité. Sveriges tidligere udenrigsminister Karin Söder påtog sig det delikate hverv som formand. Det var første skridt på den vej der siden kom til at give Nordisk Råd baggrund for den kraftige støtte til de baltiske landes frigørelse fra Sovjet.

I de følgende par år var debatterne både ved Nordisk Råds sessioner og i Præsidiet præget af især udviklingen østpå. Alle havde vist oprindelig forestillet sig i 1986-87 at vi i Nordisk Råd først og fremmest skulle udnytte resultaterne af Söder-komiteens arbejde til at fremme arbejde med EF- og EFTA-spørgsmål, men udviklingen i Sovjet og de baltiske lande blev så påtrængende at Præsidiet måtte forholde sig klart til den. Det var lettere sagt end gjort. De danske medlemmer af Nordisk Råds Præsidium i den periode var Anker Jørgensen og Lilli Gyldenkilde.

I Prasidiet aftalte man på et tidligt tidspunkt at man ville prøve at udbygge de hidtidige kontakter til Sovjets "parlamentariske" dimension, dvs. Den Øverste Sovjet. Anker Jørgensen formastede sig endda til at arbejde for at vi skulle sende en delegation fra Nordisk Råd til de baltiske lande for at få etableret noget der kunne ligne parlamentarikerkontakter.

Den tanke havde bred støtte i den danske delegation op til Nordisk Råds ekstrasession i Mariehamn i november 1989, og Karin Söder støttede den også i Præsidiet. En del af besværet med at få delegationen af sted skyldtes sovjetisk afvisning, men en lige så stor del skyldtes intern modstand i Norden - dog ikke i Danmark. Den norske statsminister Gro Harlem Brundtland var bekymret for Norges forhandlinger med Sovjet om grænsedragning i Barentshavet, et problem der først blev løst endeligt i 2011. Hun ville ikke have at nogen fra de andre nordiske lande skulle forstyrre processen. Tænk også lige på Treholt-affæren. Hendes holdning kan man forstå. Men den svenske statsminister Ingvar Carlsson var også imod; mit gæet er at han ikke brød sig om at Karin Söder, 
udenrigsminister i Torbjörn Fälldins regering, som aktiv medspiller sammen med Anker Jørgensen skulle få hjemlig politisk ære af en så markant indsats - hun repræsenterede Centerpartiet. Sådan kan politik jo også være.

I Præsidiet tog man afvisningerne i Mariehamn i 1989 med fatning. Anker Jørgensen følte at vi i Nordisk Råd havde en moralsk pligt til at forsvare folkenes selvbestemmelsesret som princip og derfor ikke rigtig havde andet valg end at arbejde til støtte for de baltiske landes frigørelse fra Sovjet. Engang lidt ind i 1990erne efter at balterne havde fået deres selvstændighed i august 1991, spurgte jeg Anker Jørgensen i en stille stund om ikke han havde været bange, for vi vidste jo ikke om Moskva ville reagere som i Ungarn i 1956 eller Tjekkoslovakiet i 1968. Jo, sagde han, men vi havde ikke noget valg.

Internationalt var det ikke specielt let. Nok havde Gorbatjov løsnet noget med sin perestrojka og glasnost, men han ville ikke lade balterne udtræe af unionen af sovjetrepublikker. I marts 1989 besatte den sovjetiske hær en række bygninger i Vilnius og smadrede radiotårnet, men heldigvis brugte de så kun ikke-militære pressionsmidler såsom at lukke for de vigtige olietilførsler. I juni 1989 fik vi i Nordisk Råd et brev fra Kreml om at vi var velkomne i Moskva, Letland og Estland, men vi kunne ikke få visum til Litauen. Præsidiet besluttede derfor at udsætte rejsen til det blev muligt at besøge alle tre baltiske lande. Det blev til en rejse dagene 14.-20. oktober 1990.

USA støttede på det tidspunkt klart Gorbatjov fordi man anså ham for at være den sikreste garant for en fredelig fornyelse i Sovjet, og han ville ikke lade de baltiske lande udtrade af unionen. Det var vel også baggrunden for Pentagons interesse for lille mig. Der var faktisk ikke andre end Nordisk Råd der fastholdt de baltiske landes problem på den internationale dagsorden. Da Anker Jørgensen i maj 1991, hvor de baltiske lande stadig var sovjetiske republikker, som Nordisk Råds præsident deltog som gæst ved Natoparlamentarikernes møde i Madrid, var han den eneste der fra talerstolen omtalte de baltiske lande. Han havde aftalt det med de amerikanske delegater, og de var glade for at han gjorde det, for de kunne ikke selv gøre det af hensyn til forholdet til Gorbatjov.

Sagen var også interessant for Pentagon, det amerikanske forsvarsministerium med CIA. I 1990 blev jeg kontaktet af en bekendt på den amerikanske ambassade i København som spurgte om et par af hans kolleger måtte komme og besøge mig for at høre lidt om det nordiske samarbejde. Det måtte de naturligvis gerne. Det var et par tiltalende yngre kvinder der kom. Jeg troede først de ville 
orienteres om det fortræffelige nordiske samarbejde med kulturpolitik, miljøpolitik, åbne grænser osv. Det viste sig imidlertid hurtigt i samtalen at de var særdeles velforberedte. De ville frygtelig gerne høre om hvad vi gik og lavede i spørgsmålet om de baltiske lande, så jeg måtte jo lige stramme mig an. Ikke noget med at hælde vand ud af ørerne her.

De må vist have lavet en tilfredsstillende rapport til Pentagon, for jeg hørte aldrig mere fra dem. Men min sovjetiske kontakt fortsatte.

I den fase var jeg skamløs nok til at bede min styringsagent Sergei ... både om at give visse meldinger til sit system og til at hjælpe med gode råd om lidt diplomati. Jeg fik den anbefaling at når kun Sverige og Finland havde anerkendt Sovjets annektering af de baltiske lande, mens Danmark, Norge og Island ikke havde, måtte en delegation nødvendigvis indlede sin eventuelle rejse i Moskva hos repræsentanter for Den Øverste Sovjet.

Anker Jørgensen var helt opmærksom på hvor delikat situationen var, og at han måske havde presset lidt hårdt på; så på et ret sent tidspunkt meddelte han at han ikke ville med på rejsen, for hans person skulle ikke bidrage til vanskeligheder. Delegationen blev så ledet af altingsmand Páll Pétursson, Island, der var Rådets præsident det år, og Karin Söder og bestod af yderligere 5 parlamentarikere med national og partimæssig bredde, fra Danmark Lilli Gyldenkilde; delegationen kom af sted i november 1990. Jeg var med i egenskab af ledsagende embedsmand som det kaldes. Den måtte af diplomatiske grunde indlede besøgene med et ophold i Moskva. Her blev den modtaget af selveste formanden i Den Øverste Sovjet, Lukjanov, og Den Russiske Føderations næstformand Khasbulatov. De indskærpede at delegationen ikke skulle blande sig i unionens indre anliggender når den kom til de baltiske lande! Så vi skulle ikke ryste på hånden. I Moskva tog den danske ambassadør sig pænt af Lilli Gyldenkilde og mig, men han kunne ikke rejse med på den videre færd til de baltiske lande fordi Danmark aldrig havde godkendt anneksionen. Så i de baltiske lande fik vi hele holdet hjælp af den svenske generalkonsul i Leningrad.

Vore værter i de baltiske lande var de lokale sovjetter; de var nu de drivende i selvstændighedsbestræbelserne efter at frigørelsesfolkene, folkefronterne, ved valg i februar 1990 havde vundet flertal i de lokale sovjetter, og de havde proklameret de baltiske landes selvstændighed - men det ville Sovjet ikke anerkende på det tidspunkt. Vore værter nærmest tryglede om at få offentlige støtteerklæringer til fordel for selvstændigheden. Vi kunne dog godt huske formaningen fra Den Øverste Sovjet, så ... For selvfølgelig 
blev hver en bevæelse fulgt af KGB. Det var heller ikke den letteste opgave for os embedsmænd undervejs og mens tingene hele tiden forskød sig, at skrive nye underlagspapirer til politikerne. Men det var bestemt heller ikke kedeligt. Karin Söder havde været det man i Sverige kaldte förskollärarinna, og når hun sagde "hör ni, pojkar', vidste vi at der skulle tages fat.

\section{Sådan løser man et dilemma}

I Riga bød den lokale sovjet på middag og forventede en støtteudtalelse da Páll Pétursson skulle sige tak for mad på gæsternes vegne. Han var en stor rund bondemand fra Nordisland og besindigheden selv, men den dag var han godt nervøs. Jeg spurgte om jeg skulle skrive et taleudkast til ham. I parentes bemærket havde jeg skrevet udkast til ham før som han havde været godt tilfreds med, blandt andet hans tale som rådspræsident til mindehøjtideligheden for Palme i sin tid. Han afviste mig nærmest vrissent, så anspændt var han.

Men han løste dilemmaet: Han stillede sig op og fortalte om Islands selvstæendighedskamp mod Danmark! Balterne undrede sig først. Men så gik det op for dem at han fik sagt at det nok skulle lykkes, at de ikke skulle bruge våben, og at vi er gode venner bagefter. Lilli Gyldenkilde sad ved siden af ham og var begejstret.

Rejsen viste sig også nyttig ved at sætte os i forbindelse med nogle af de ledere som overtog magten efter løsrivelsen - også selv om kun få af dem kom til at sidde ved magten i læengere tid efter selvstændigheden; de fleste fik dog ganske fremtræedende poster gennem årene derefter.

Det forholdt sig anderledes med de ledere vi mødte i Moskva på rejsen: formanden i Den Øverste Sovjet, Lukjanov, og Den Russiske Føderations næstformand Khasbulatov. De prøvede kort efter at gøre oprør mod Gorbatjov - og havnede i fængsel.

Delegationsrejsen blev et symbol for de nordiske landes støtte til de baltiske folks frihed og selvstændighed. Og markeringen fra alle Nordisk Råds medlemmer af en kollektiv sympati betød specielt meget fordi den bidrog til at styrke uafhængighedskravenes legitimitet på en måde som regeringsapparaterne og diplomatiet ville have vanskeligt ved.

I januar 1991 angreb sovjetiske tanks tv-tårnet i Vilnius for at stoppe fri information. Der var flere dræbte. Og både i Riga og Vilnius byggede borgerne barrikader for at beskytte deres parlamentsbygninger. 


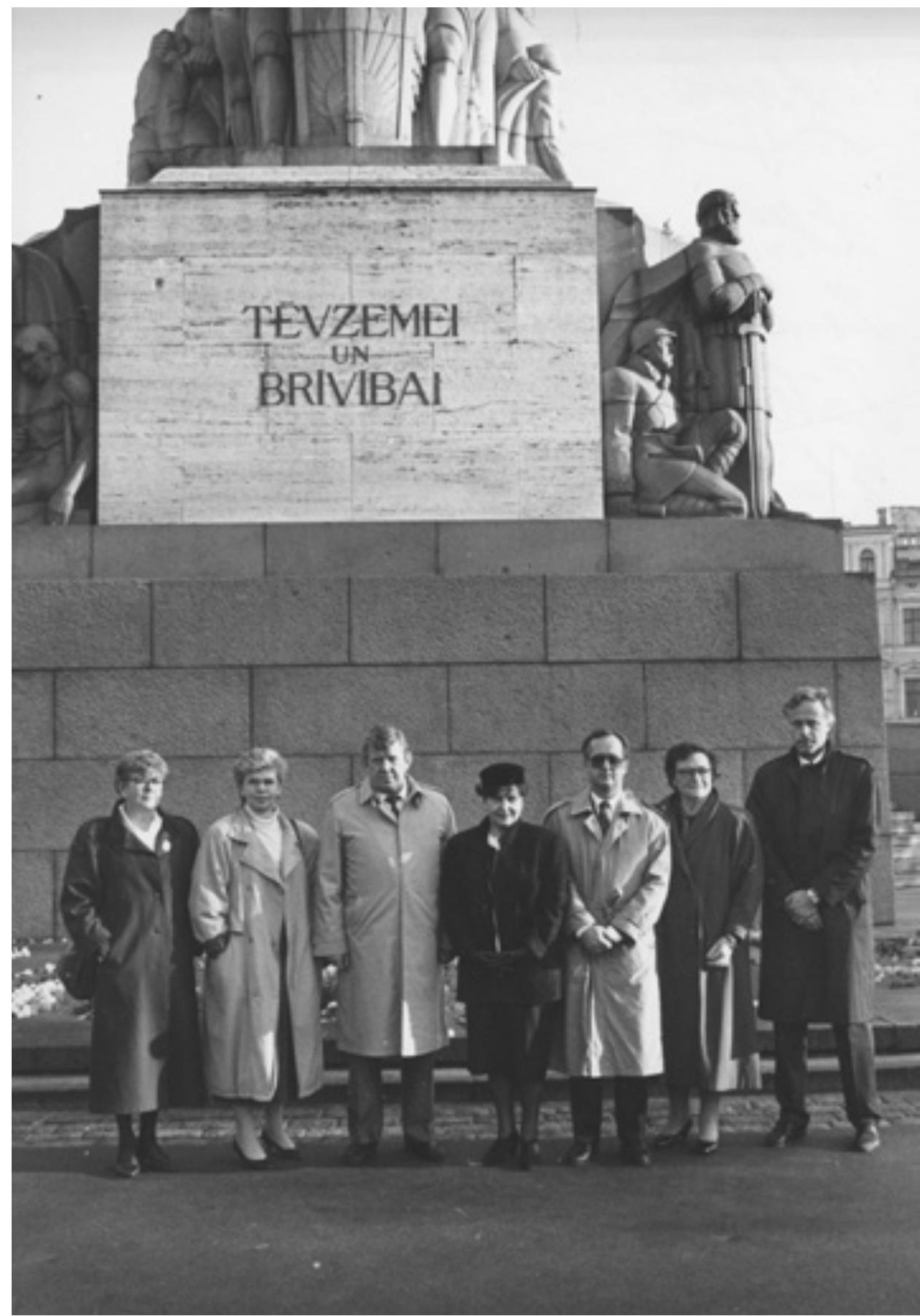

"For fadreland og fribed". Deltagerne i Nordisk Råds Prasidiums delegation til de baltiske lande fotograferet foran fribedsmonumentet $i$ Riga oktober 1990. Monumentet i fornem jugendstil blev indviet $i 1935$ til minde om ofrene $i$ krigen der førte til Letlands selvstandigbed $i$ 1918. Nordisk Råd-medlemmerne er fra venstre: Lilli Gyldenkilde, Danmark; Berit Oscarsson, Sverige; Páll Pétursson, Island; Else Hetemäki-Olander, Finland; Johan Løken, Norge; Karin Söder, Sverige; Mats Nyby, Finland. Billedet tilhører Henrik Hagemann. 
Da Jan P. Syse, Norges tidligere statsminister, Anker Jørgensen, Danmarks tidligere statsminister, og Karin Söder, Sveriges tidligere udenrigsminister, i januar 1991 som repræsentanter for Nordisk Råds Præsidium besøgte Vilnius og Riga, oplevede de at stå i 20 graders kulde uden for tv-tårnet i Vilnius og se Sovjetmagten demonstrere sin afmagt ved at køre rundt i gaderne med kampvogne, som Karin Söder fortæller det. ${ }^{5}$

I Præsidiet vedtog man i januar 1991 en udtalelse hvori man udtrykte stor bekymring over den militære aktivitet som fandt sted fra sovjetisk side i de baltiske stater. Præsidiet understregede at den positive udvikling i Østersøområdet måtte have lov at fortsætte på fredelig vis og tage hensyn til princippet om selvbestemmelse for alle folk.

\section{Diplomatisk furore}

I februar 1991, altså stadig i den tid da de baltiske lande fortsat var sovjetrepublikker, afholdt Nordisk Råd session i København, og vi havde indbudt repræsentanter fra hver af selvstæendighedsbevæelserne til at komme til sessionen og tale til os. De indbydelser vakte stor diplomatisk furore. De sovjetiske ambassadører i alle de nordiske lande skrev skarpe protestbreve til de respektive formænd for Nordisk Råd-delegationerne og til udenrigsministerierne. Brevene indeholdt også en besværen sig over at der ikke var indbudt repræesentanter for Sovjetunionen, og en kritik af den nordiske Baltikumpolitik. I brevet til Anker Jørgensen hed det bland andet "Det har forbavset os og berørt os dybt, at de første og mest kategoriske til at udtale sig var visse statsmænd og politikere fra Norden, den region, som selv i konfrontationens år udmærkede sig ved nøgterne vurderinger, og hvorfra man kunne høre fornuftens og beherskelsens stemme. (...) I enkelte af de nordiske lande, som vi betragter som vore gode naboer, har der vist sig et åbenlyst ønske om at tækkes de centrifugale og destruktive kræfter i Sovjetunionen og gøre det sværere for os at overvinde vore vanskeligheder inden for rammerne af Sovjetunionens forfatning og på et legitimt grundlag (...).”

Jeg spurgte Anker Jørgensen hvad vi skulle stille op med det brev. Ingenting, sagde han. Jeg fik åbenbart brevet af ham under sessionen, for det er i vort arkiv stemplet "Modtaget 5. marts 1991", dvs. efter sessionen. Det må være sendt direkte til ham på Christiansborg, og vi har ikke haft tid til at journalføre det i sekretariatet under sessionen. Moskvas advarsel var imidlertid et interessant tegn på at man lyttede til hvad Rådet foretog sig. Eller som Karin

5 "50 år til nordisk nytte" s. 201. 
Söder udtrykte det: Ju mer vi blir kritiserade, desto starkare står vi.

Finlands præsident Koivisto skrev op til denne session et alvorligt brev til den finske delegations medlem Claes Andersson med kopi til hele den finske delegation. I dette brev undrede præesident Koivisto sig over at Vänsterförbundet, Claes Anderssons parti, ikke kunne følge den udenrigspolitiske ledelses linje i spørgsmålet om Baltikum. Før den seneste grundlovsrevision i Finland var det suverænt republikkens præsident der bestemte Finlands udenrigspolitik, så det var svært, det her. Præsident Koivisto skrev at efter hans opfattelse burde Nordisk Råd overhovedet ikke beskæftige sig med spørgsmålet om forholdet til de baltiske lande. Værsgo'. Det brev lettede ikke hverken i Norden eller Baltikum forståelsen for Finlands linje. ${ }^{6}$

Præsidiemødet lige forud for sessionens begyndelse var vanskeligt. Man skulle fastlægge drejebogen for hvordan det hele skulle foregå med de baltiske gaster, og det var ikke helt let. Den finske delegations formand Elsi Hetemäki-Olander følte sig presset fra to sider; på den ene side præsident Koivistos meget restriktive linje, på den anden side presset fra dem der ønskede at Nordisk Råd skulle fremsætte vidtgående udtalelser.

Man blev i Præsidiet enige om at sessionen skulle afbrydes på et bestemt tidspunkt. Så skulle balterne følges ind i folketingssalen som gæster, Anker Jørgensen skulle som rådets præsident byde dem velkommen fra formandsstolen, og en fra hvert af de baltiske lande skulle så få lejlighed til at holde en slags hilsningstale. Efter den sidste taler skulle Anker Jørgensen sige pænt tak, og gæsterne skulle så følges ud af folketingssalen.

Gæsterne var Arnold Rüütel, formand for Estlands Øverste Sovjet; Anatolijs Gobunovs, formand for Letlands $\emptyset$ verste Sovjet, og Bronislovas Kuzmickas, næstformand for Litauens $\emptyset$ verste Sovjet. Desuden havde Præsidiet indbudt Walther Paulis, næstformand for Benelux' Interparlamentariske Råd, og Jan Verbeek, næstformand for Europarådets Parlamentariske Forsamling.

Da Anker Jørgensen havde budt velkommen, afsluttede han imidlertid velkomsten med bl.a. at sige at efter de tre taler var der mulighed for rådets medlemmer for at stille spørgsmål til gæsterne således at vi på den måde kunne få en vis udveksling af synspunkter. Jeg sad ved siden af ham i sekretærstolen og vidste rent ud sagt ikke hvad pokker jeg skulle gøre. Præesidiet havde netop

6 "50 år til nordisk nytte" s. 184. 
besluttet at der ikke skulle være debat med de baltiske gæster, og det vidste alle rådets medlemmer. Jeg kunne ikke begynde at diskutere med Anker Jørgensen åbent mens han sad i formandsstolen. Jeg skrev derfor en seddel og lagde op til ham med ordlyden "det var ikke helt det I havde aftalt i Præsidiet". Han trykkede på afbryderen til sin mikrofon, lænede sig over mod mig og sagde "næh, men nu har jeg sagt det". Den finske delegationsformand kom op og var ved at flå mig levende i bar vrede, og Lilli Gyldenkilde sagde med et grin bagefter "jeg tror sgu' han gjorde det med vilje".

Det var en streg i regningen. Og der var altså en parlamentariker der bad om at få ordet. Så viste delegationerne deres diplomatiske formåen og sendte en fin taler fra hver partigruppe på talerstolen for at holde en kvitteringstale og på forsigtig vis bevidne vor støtte til deres bestræbelser, blandt dem Carl Bildt. Det her skulle i hvert fald ikke skabe alt for store problemer i forholdet til Sovjet. Til gengæld blev dette arrangement en stærkere fællesnordisk markering end Præsidiet havde tænkt sig. Anker Jørgensen tog det helt roligt.

\section{Hvad kom denne session til at betyde for de baltiske gaster?}

Ved en uformel middag vistnok sidst i $1992 \mathrm{kom}$ jeg til at sidde over for Arnold Rüütel. Han var netop gået af som præsident i Estland og afløst af Lennart Meri. I forbindelse med de baltiske gæsters deltagelse i sessionen året inden, altså før løsrivelsen fra Sovjet, havde jeg haft en del kontakt med dem. Jeg spurgte derfor hvad den session havde betydet for gasterne.

Rüütel svarede at det ikke kunne vurderes højt nok. Sessionen havde givet gasterne mulighed for kontakt med Vesttysklands udenrigsminister Hans-Dietrich Genscher gennem Vesttysklands ambassade i København, og sessionen havde været et stærkt signal til Sovjetunionen om en nordisk politisk opinion.

Han var desuden taknemlig for at Nordisk Råd som eneste formelle politiske organ i verden havde fastholdt de baltiske landes problemer på den internationale politiske dagsorden, jf. også Anker Jørgensens tale ved Nato-parlamentarikernes møde maj 1991.

\section{Fart på igen}

Nordisk Råds Præsident i 1991, Anker Jørgensen, var ikke helt tilfreds med regeringernes indsats i det nordiske samarbejde. I hvert fald ringede han til mig en dag sidst på foråret og spurgte hvem der var formand for statsministrene. Jeg svarede som sandt var at Esko Aho i Finland var statsministrenes formand. "Jeg vil over og tale 
med ham, nu må statsministrene på banen" sagde Anker Jørgensen, og vi fik arrangeret at Anker Jørgensen og præsidiesekretæren drog til Helsingfors.

Anker Jørgensens møde med Esko Aho ledte frem til en tydelig henstilling fra Nordisk Råds Præsidium til statsministrene om at udstikke retningen for det nordiske samarbejde i 1990erne. Den henstilling fulgte statsministrene med Mariehamnsdeklarationen som havde temaet "Norden efter 1992". Den blev et vigtigt skridt i det nordiske samarbejdes muligheder efter 1991.

Jeg skal ikke gøre mig klog på om det i virkeligheden var en opbremsning at statsministrene kom så meget på banen. Finlands Claes Andersson udtalte i hvert fald ved sessionen i marts 1992: "Nu har det alltså hänt: statsministrarna kapat makten i Nordiska rådet."

Ved samme session i Helsingfors i marts 1992 talte forbundskansler Helmuth Kohl. Det var naturligvis en flot gestus over for Nordisk Råd og de nordiske lande.

En stor politiker på det niveau har selvfølgelig fortrinlige taleskrivere. Det betyder imidlertid også at når taleren afviger fra sit manuskript, afsløres det nemt i hvor stor udstrækning politikeren selv behersker sit stof. Helmuth Kohl imponerede mig virkelig. Jeg havde det held at jeg inden talen blev holdt, havde fået en kopi af manuskriptet og derfor kunne se hvor han i sin tale afveg fra manuskriptet; det gjorde han flere gange på en lysende måde! Og der var altså ikke noget i vejen med udkastets kvalitet.

Et stort flertal i Nordisk Råd ønskede i 1992 oprettet et ministerråd for udenrigsministrene, men det ville regeringerne overhovedet ikke være med til. Til belysning af hvor meget spændingen i Norden var aftaget siden Sovjets sammenbrud, skal jeg lige fortælle at det dog lykkedes Nordisk Råds Præesidium i foråret 1992 at få en aftale med statsministrene om at regeringerne ville afgive en udenrigs- og sikkerhedspolitisk redegørelse til Nordisk Råd. Det var aldrig sket før. Og formelt blev det også skarpt afgræenset, ikke noget med rekommandationer som regeringerne skulle føre ud i livet, ikke noget med et Nordisk Ministerråd for udenrigsministrene, for så skulle de jo også afgive beretninger til Nordisk Råd. Så stramt er det trods alt stadig! Så sent som i foråret 2013 behandlede Nordisk Råds Præsidium et forslag fra Bertel Haarder om oprettelse af et ministerråd for sikkerhedspolitik: det fik ikke tilslutning.

Ved den session vi så afholdt i Århus november 1992 om det udenrigspolitiske samarbejde, afgav Thorvald Stoltenberg, Norges uden- 
rigsminister, redegørelsen på regeringernes vegne. Uffe EllemannJensen deltog også i debatten. Peder Sønderby, et af Venstres medlemmer af Nordisk Råd, gav ham efter talen en 10-øre for at drille ham. 10-øren blev givet til nyvalgte medlemmer af Folketinget efter deres jomfrutale i Folketinget. Det kunne Uffe Ellemann godt lide.

Men i regeringskontorerne var parlamentarisk indblanding i den svære udenrigspolitik stadig ikke velset. I 1993, altså året efter, skulle den svenske udenrigsminister afgive regeringernes redeg $\varnothing$ relse og også medtage en sikkerhedspolitisk redegørelse. En ledende medarbejder i det svenske udenrigsministerium ringede til vor daværende præsidiesekretær og spurgte hvem der havde bestemt at hans minister skulle afgive en redegørelse til Nordisk Råd. Han fik prompte svaret at det var aftalt med statsministrene. Ministeren kom, og hun holdt en god tale. Men det var og er fortsat enestående at regeringer afgiver fælles sikkerhedspolitiske redegørelser til offentlig debat i et tværnationalt parlamentarikerforum.

I den debat talte også den norske udenrigsminister Thorvald Stoltenberg. Han har altid været meget direkte. Han sagde bl.a. lige ud at også i alle årene efter den 2 . verdenskrig havde de nordiske udenrigsministre trods den kolde krig mødtes jævnligt. De havde kun ét punkt på den officielle dagsorden, nemlig FN's fredsbevarende aktioner; det var jo uproblematisk i forhold til Sovjet. Men de havde selvfølgelig talt grundigt sammen om alle de svære sager i international politik: Koreakrigen, Ungarn 1956, Cubakrisen 1962, Tjekkoslovakiet 1968, Vietnamkrigen osv. og i høj grad afstemt de nordiske landes optræeden i FN. Hvad det har betydet under den kolde krig især for Finland som nabo til Sovjet, kan enhver forstå.

Da Søren Gade i sin tid som forsvarsminister skulle afgive en tilsvarende redegørelse for Nordisk Råd, var han godt nervøs over for den efterfølgende debat, for han havde aldrig deltaget $i$ arbejdet i Nordisk Råd. De erfarne danske medlemmer beroligede ham med at han da var blandt venner. Den ivrigste deltager i debatten var dansk - det var Line Barfod, Enhedslisten, og hende var han helt fortrolig fra Folketinget med at debattere med.

Det arbejde vi gjorde især med støtten til de baltiske lande, og som regeringerne selvfølgelig intensiverede yderligere efter 1991, det medvirkede til at de kunne blive medlemmer af EF. De fik en associeringsaftale i $1995 \mathrm{og}$ medlemskab i 2004. I første fase af EF's behandling af ansøgningerne om optagelse var der ikke helt fodslag mellem Danmark, Finland og Sverige - de tre nordiske 
medlemmer. Finnerne prøvede at promovere deres fæller i Estland frem for Letland og Litauen, men især Poul Nyrup Rasmussen pressede på og fik igennem at de baltiske lande skulle optages samtidig. Og de blev medlemmer af NATO også i 2004.

Hvad det har betydet for forholdet til Rusland, kan ikke vurderes højt nok. Rusland betragtede og betragter reelt stadig de baltiske lande som russisk interessesfære, som man kaldte det engang. I debatterne ved de parlamentariske Østersøkonferencer har det ikke altid været let at holde en rimelig tone, fx i spørgsmålet om olierørledningen gennem Østersøen fra St. Petersborg til Nordtyskland eller de store russiske olietransporter pr. skib fra Primorsk gennem den Finske Bugt og Østersøen.

\section{Baltisk Forsamling og Baltisk Råd}

Den vellykkede nordiske indsats til støtte for de baltiske landes frigørelse fra Sovjetunionen førte til et ønske både blandt regeringerne og parlamentarikerne om at oprette reelle samarbejdsorganer både mellem de baltiske lande og Norden og mellem alle lande i Østersøområdet.

I begyndelsen af 1990erne kom der fra flere sider forslag om at de baltiske lande skulle optages som medlemmer i Nordisk Råd. Et medlemsforslag i Nordisk Råd fremsat af det danske medlem Kristen Poulsgaard blev afvist med den enkle begrundelse at der ikke forelå nogen ansøgning fra nogen af de baltiske lande. Og i en senere uformel samtale mellem den daværende formand for Nordisk Råds Danske Delegation Knud Enggaard (vistnok i 1993) og repræsentanter for Baltisk Forsamlings ledelse beskrev Enggaard forholdet således: "De nordiske lande er én familie, og de baltiske lande er én familie; de to familier kan sagtens mødes med mellemrum, men de er to familier."

De baltiske lande oprettede ret hurtigt Baltisk Forsamling delvis efter model fra Nordisk Råd, og de baltiske regeringer oprettede Baltisk Råd. Kontakten mellem Baltisk Forsamling og Nordisk Råd blev hurtigt nær i form af deltagelse i hinandens sessioner, udvalgsarrangementer og lignende. Men der var grænser for hvor langt man alligevel i de baltiske lande ville gå fx i retning af at efterligne Nordisk Råds og Nordisk Ministerråds indbyrdes forhold.

På et tidspunkt gennemgik jeg således Nordisk Råds forretningsorden for Baltisk Forsamlings daværende sekretær og anbefalede en indsats for at sikre et formelt grundlag for et tillidsfuldt samspil mellem parlamentarikerne og regeringerne sådan som det fx er udtrykt i reglerne for rekommandationer og beretninger og $\mathrm{i}$ 
reglerne for spørgsmål fra medlemmer til ministre. Hun var dybt imponeret, men anså det for helt udelukket at de baltiske regeringer overhovedet ville være med til noget i den retning. Ligeledes var hun meget, meget skeptisk over for om man kunne få partigrupper til at fungere bare tilnærmelsesvis på tværs af landegrænser som vore partigrupper gør. Arbejdet i Baltisk Forsamling var og er helt og holdent organiseret på national basis; afstemninger i plenum går således efter nationale skillelinjer, ikke partilinjer.

\section{De parlamentariske Østersøkonferencer og regeringernes Østersøråd}

En god frugt af indsatsen sidst i 1980erne er vore dages parlamentariske $\emptyset$ stersøsamarbejde ${ }^{7}$.

Allerede i 1990 vovede Kalevi Sorsa, formanden for Finlands riksdag, at indbyde til en parlamentarikerkonference om samarbejde i Østersøområdet ${ }^{8}$. Den blev holdt i januar 1991, altså mens de baltiske lande stadig var dele af Sovjetunionen. Talerne på denne konference samlede sig om emnerne økonomi, miljø, kultur og politik.

Konferencen havde ikke mandat til at træffe nogen formelle beslutninger eller til at vedtage noget slutdokument. Det ville også have været for meget at forvente i betragtning af Sovjetunionens modvillige deltagelse, eftersom Estland, Letland og Litauen deltog med selvstændig repræsentation skønt de stadig var republikker i Sovjetunionen.

Men konferencen var en god begyndelse. Både Nordisk Råd og regeringerne greb mulighederne.

\section{Regeringerne klar til udrykning}

Så snart de baltiske lande i august 1991 havde fået accepteret fuld uafhængighed, gik udenrigsminister Uffe Ellemann-Jensen og Vesttysklands udenrigsminister Hans-Dietrich Genscher for alvor i gang med forberedelserne til etablering af Østersørådet. Udenrigsministrene fra alle Østersøstaterne + EU-Kommissionen mødtes i København i marts 1992 og blev enige om at oprette Østersørådet, "The Council of Baltic Sea States", med henblik på

7 Se fx. "20 Years of Parliamentary Commitment", red. af Jan Widberg, udg. af Nordisk Råd 2011.

8 Den første parlamentariske $\emptyset$ stersøkonference havde deltagelse fra Danmark, Estland, Finland, Færøerne, Grønland, Hamborg, Island, Karelen, Letland, Litauen, MecklenburgForpommern, Norge, Polen, Slesvig-Holsten, Sovjetunionen, Sverige og Ålandsøerne og med observatører fra FN's Økonomiske Kommission for Europa, EFTA, Helsingforskomiteen, Den Interparlamentariske Union, Nordisk Råd og Europarådet. 
at opbygge demokratiske institutioner i regionen og samarbejde om økonomi, kultur, miljø, atomsikkerhed og sociale forhold. I dag er Østersørådet som bekendt en af de vigtigste aktører i regionen.

Da Folketinget gav mandat til den danske regering til oprettelsen af et Østersøråd, hed det i Udenrigsudvalgets betænkning fra 9. april 1992 at medlemmerne af Udenrigsudvalget med undtagelse af Fremskridtspartiet ønskede "med vedtagelsen af beslutningsforslaget at tilføje det allerede oprettede Østersøråd en parlamentarisk dimension bl.a. med henblik på samarbejde med Nordisk Råd, når dette er hensigtsmæessigt." Det var og er hensigtsmæssigt, for Nordisk Råd var drivkraften i de første mange år.

Det vedtog Folketinget med alle stemmer undtagen Fremskridtspartiets.

\section{Nordisk Råd og det parlamentariske Østersøsamarbejde}

I dagene 22.-24. april 1992 afholdt Nordisk Råd i samarbejde med Stortinget i Norge den 2. parlamentariske Østersøkonference.

Konferencen fandt sted i Oslo af taktiske grunde for at markere at Norge og også Island hørte med i denne sammenhæng, og den endte med det $ø$ nskede resultat.

Forventningerne til den var høje. De baltiske stater var i færd med at opbygge deres uafhængighed og håbede på støtte til deres forventninger. Sovjetunionens opbrud i 1991 havde skabt en helt ny situation i Østersøområdet og åbnet nye perspektiver.

Deltagerne skulle udvikle en plan for samarbejdet, og de skulle finde ud af hvordan den parlamentariske dimension skulle tilgodeses i lyset af regeringernes Østersøråd.

Debatten var ind imellem ganske hård. De baltiske lande ønskede at samarbejdet skulle indbefatte sikkerhedspolitik og kræevede at russiske tropper skulle trækkes tilbage fra deres lande. Sovjets repræsentanter protesterede mod at dette emne skulle inddrages, og blokerede for videre diskussion om det. Men på den anden side fandt de at parlamentarikerkonferencen var et godt forum for drøftelse af mindretalsproblemer, her underforstået de russiske mindretal i de baltiske lande.

Den ene af de lettiske delegater havde jeg mødt på vores besøg i Riga på den omtalte delegationsrejse i oktober 1990. Han var stadig meget, meget russerfjendsk, og i en pause hvor den russi- 
ske delegationsleder lige inden havde været ret kritisk over for balternes deltagelse, gav letten udtryk for sin vrede ved at sige til mig "vi har også våben". Jeg blev selvfølgelig noget bestyrtet og sagde indtræengende "I må ikke skyde. Det vil blive en katastrofe for os alle sammen".

Det andet jeg vil nævne, er i den mere muntre afdeling. Den danske delegation blev ledet af Anker Jørgensen, men han ville ikke selv holde hovedtalen på danskernes vegne; det bad han den gamle trafikminister J.K. Hansen om. Jeg havde lavet et taleudkast til ham som han var meget tilfreds med. Før han skulle tale, havde den finske delegations talsmand ordet. Han kritiserede ganske skarpt at Danmark nu ville bygge en Storebæltsbro som havde for lille gennemsejlingshøjde over internationalt farvand til de tårne til boreplatforme som finske værfter byggede til boreplatforme $i$ Nordsøen. J.K. Hansen holdt derefter sin tale, og da han var færdig med manuskriptet, syntes han åbenbart at han som gammel trafikminister der havde været stærkt involveret $\mathrm{i}$ broprojektet, måtte forsvare det. Han var nærmest vred og brugte ret stærke ord. Derfra hvor jeg sad, kunne jeg se at der blev uro i den finske delegation. Hvad sker der nu, tænkte jeg, uden at kunne gøre noget som helst. Så bad Anker Jørgensen om ordet til en kort bemærkning, og han gik på talerstolen. Her fortalte han at han i 1977 havde aftalt med Bresjnev at den planlagte bro var helt i orden. Alle lo selvfølgelig, og spændingen var væk. Det hører dog også med i billedet at Danmark senere accepterede at betale Finland en vis kompensation.

Konferencen i Oslo skabte den første formelle ramme for det fortsatte parlamentariske samarbejde, og Nordisk Råd påtog sig at stå for sekretariatsbetjeningen.

Til at varetage opgaverne mellem de årlige konferencer nedsatte man i 1994 en såkaldt Standing Committee med 5 medlemmer; det var en repræsentant for de nordiske lande udset af Nordisk Råd, en representant for de baltiske lande udset af Baltisk Forsamling, en repræsentant for Polen, en repræsentant for Rusland og en repræsentant for Tyskland. I årene 1994-2002 var først Dorte Bennedsen og siden Svend Erik Hovmand Nordisk Råds repræsentant i Standing Committee. De fik sekretariatsbetjening både fra Nordisk Råds fællessekretariat og fra mig.

Den næste Østersøkonference havde polakkerne indvilget i at være værter for. Den fandt først sted i 1994 . Her skulle Anker Jørgensen holde en vigtig tale som repræsentant for Nordisk Råds Præsidium. Jeg havde slidt bravt med at få skrevet et ordentligt ud- 
kast til hans tale, konfereret den med gode folk i Udenrigsministeriet og med vor mand i Nordisk Investeringsbanks bestyrelse, en virkelig kompetent makker.

I den periode havde Anker Jørgensen temmelig travlt. Han havde i hvert fald ikke haft tid til at gennemarbejde talen hjemme, så vi sled i det i flyveren på vej til Warszawa. Han var god at skrive taler til, for han ville altid selv arbejde dem grundigt igennem. Og han har aldrig afvist hvad jeg kom med. Det var derfor altid hans taler, ikke mine - og det er i øvrigt også ligegyldigt. Det politisk afgørende er jo at han valgte at holde dem på det pågældende tidspunkt.

Da vi kom til hotellet - og det var altså i 1994 - lånte jeg en skrivemaskine i receptionen. Den var selvfølgelig med polske typer med alle accenttegnene. Jeg stillede den på sofabordet på mit hotelværelse og gennemskrev talen med karbonpapir. Næste morgen ved morgenmaden gav jeg Anker Jørgensen talen og sagde "nu må du ikke lave mere om, for jeg giver den også til tolkene". Det er jo altid en stor hjælp for dem at have en papirudgave også. Han skulle nok lade være med at ændre mere.

Anker Jørgensen skulle tale som nummer to den morgen. Før ham skulle den russiske føderations talsmand tale. Det var en gammel apparatjik som var ganske grov over for balterne og kritiserede dem for deres behandling af de russiske mindretal. Anker Jørgensen blev vred og indledte med en spontan skælden ud på russeren. Tolken begyndte direkte på manuskriptet. Efter talen roste de nordiske deltagere Anker Jørgensen for hans glimrende tale; nordboerne var jo de eneste der forstod hans skælden ud. De andre deltagere der fik tolkenes version, bemærkede ikke noget særligt - vi fik således ingen krig mod Rusland. Jeg holdt min mund, og jeg har aldrig turdet fortælle Anker om det.

I 1995 skulle Folketinget være vært for den parlamentariske Østersøkonference i samarbejde med Nordisk Råd. Den blev holdt på Bornholm af mange gode grunde. Vi ville meget gerne have den ene af Ruslands to viceudenrigsministre til at komme, så vi på den måde kunne prøve at forbedre forholdet mellem Rusland og de baltiske lande. Her benyttede jeg min styringsagent. Jeg fortalte ham hvor vigtigt vi anså dette for at være, og jeg bad ham indtrængende om at melde hjem til Moskva at det betød noget om viceudenrigsministeren ville komme. Det lovede Sergei ..., og ministeren kom. Hvor meget det skyldes mit pres, kan jeg ikke vide, men ministeren holdt en rimelig tale i plenum. Bagefter holdt han en pressekonference hvor han skældte ud på balterne; pressekonferencen var nok mest til hjemlig brug for ham selv. 
I årenes løb har Østersøkonferencerne udviklet sig til et gedigent forum for drøftelse af vigtige temaer: Østersøens forurening, sikkerhed til søs, menneskehandel osv. Og selv om det ikke har været muligt at opbygge samme forhold til Østersørådet som Nordisk Råd har til Nordisk Ministerråd, er samspillet dog blevet stadig forbedret. Således afgiver Østersørådets formandskab hvert år en slags beretning til den parlamentariske Østersøkonference, og den danske regering afgiver nu også en redegørelse til Folketinget sammen med redegørelsen for dens nordiske samarbejde.

Organisatorisk har udviklingen været den at især de enkelte baltiske lande har ønsket at hvert af konferencernes deltagende parlamenter skulle have en plads i Standing Committee og samtidig bidrage til finansiering af sekretariatet.

I mine øjne er det tydeligt at de første parlamentariske Østersøkonferencer i høj grad tilkendegav et generelt ønske om samarbejde; heldigvis er udviklingen klart gået i retning af mere og mere fokuserede konferencer med behandling af konkrete og væsentlige politiske emner. Og somme tider også ganske åbenhjertige uenigheder og diskussioner; et godt tegn for et seriøst politisk arbejde.

\section{Og det arktiske}

En anden udløber af indsatsen i Nordisk Råd i årene 1986 og frem er opbygningen af det arktiske regeringssamarbejde i Arktisk Råd og det parlamentariske samarbejde i det organ som nu kaldes Arktisk Komité.

Til Nordisk Råds session i Helsingfors i marts 1992 havde Islands tidligere udenrigsminister Halldór Ásgrímsson fremsat et forslag om samarbejde i det arktiske område.

På sommermødet i Nordisk Råds Præsidium på Svalbard i 1992 blev Præsidiet ved studiebesøg i norske og russiske bosættelser og ved foredrag af eksperter temmelig grundigt orienteret om bl.a. biologi, geologi, glaciologi, meteorologi og historie i det arktiske område, og Halldór Ásgrímsson indledte en debat om de politiske aspekter. Vi fik på den måde et ret grundigt og aktuelt billede af udfordringer og muligheder i den arktiske region.

Præesidiet indbød derfor året efter til en international parlamentarikerkonference om fremtidigt arktisk samarbejde; den blev holdt i Reykjavík i august 1993. Denne konference ledte hurtigt frem til oprettelsen af Arktisk Komité (det formelle navn er Standing 
Committee for the Parliaments of the Arctic Region, kaldet SCPAR).

Og Arktisk Komité virkede aktivt sammen med Nordisk Råd for etableringen af regeringernes Arktisk Råd.

Arktisk Komité har staterne omkring Nordpolen, dvs. de nordiske lande, Canada, Rusland og USA, som medlemmer med hver ét medlem + Inuit Circumpolar Conferences (eskimoernes tværnationale organisation) som observatør med én repræsentant. Folketingets repræsentant udses af Nordisk Råds Danske Delegation efter bemyndigelse fra Folketingets Præesidium. Også de russiske oblaster, de canadiske delstater og Alaska som delstat vil gerne have observatørstatus, men det har hverken USA, Canada eller Rusland villet gå med til. Det har også ramt Grønland som af indlysende grunde ønsker at deltage så aktivt som muligt i samarbejdet om arktiske forhold.

Det med Grønlands deltagelse var ikke det store problem så længe Inuit Circumpolar Conferences havde grønlandsk formand (Aqqaluk Lynge indtil 2006), for han deltog jo med taleret i møderne i Arktisk Komité. Men da han i 2006 blev afløst af en canadisk kollega, var Grønland uden ansigt og stemme i Arktisk Komité.

Jeg blev ringet op af Grønlands Landstings daværende direktør Nikolaj Sørensen, som satte mig ind i situationen. Min daværende delegationsformand, fhv. minister Ole Stavad, var indstillet på at vi skulle prøve at finde en løsning der også var tilfredsstillende for Grønland. Det var der tilslutning til i delegationen. I første omgang valgte man at lade som om at det ikke kunne være noget problem at Folketinget sendte to repræsentanter til møderne i Arktisk Komité, hvoraf den ene var det ene af de to folketingsmedlemmer der var valgt i Grønland. Det voldte faktisk ingen problemer, og Grønland fik på den måde direkte kontakt.

I dag sender Folketinget mig bekendt kun et medlem til møderne i Arktisk Komité som repræsentant for rigsfællesskabet, og respekten for den grønlandske indsats er nu så solid at komitéen har valgt det grønlandsk valgte folketingsmedlem Sara Olsvik som formand fra september 2013. Og Arktisk Komité er pænt på vej til at få godt fodfæeste som et parlamentarisk forum vis-a-vis Arktisk Råd.

Udenrigsministrene kom også for alvor i gang med at arbejde for oprettelsen af samarbejdsorganet Arktisk Råd. Det var en ret sej 
proces. Amerikanerne var ret tøvende, men Rådet blev da etableret i 1996. Først i 2013 fik det et eget sekretariat (i Tromsø) skønt der var blevet presset på i flere år fra nordisk side.

Behovet for en indsats ses måske tydeligst af den internationale interesse for Arktisk Råd. Tyskland, Holland, Polen, Spanien og Storbritannien har permanent observatørstatus, og EU vil gerne være med; Japan, Kina, Sydkorea og flere andre banker også på. Det bliver interessant at følge udviklingen i det samarbejde, som foreløbig er forløbet ganske fredeligt, heldigvis.

\section{Hvad bliver det næeste?}

Nordisk Råds aktive indsatser uden for Norden begyndte med støtten til Estlands, Letlands og Litauens selvstændighed, fortsatte med Østersøsamarbejdet og indbefatter nu også det arktiske. Og samtidig har Rådet jo engageret sig til stadighed i det traditionelle interne samarbejde i Norden, især med arbejdet for at få fjernet grænsehindringer og forebygget nye. Men det er en anden historie.

\section{Slut på spionhistorien}

I foråret 1996 kom der en mand ind på mit kontor. Døren stod næsten altid åben. Denne mand kom ind og lukkede døren indefra. Det var jeg ikke just vant til. Han tog et politiskilt op af lommen og præsenterede sig som kommende fra Politiets Efterretningstjeneste, PET. Han kom i anledning af de fortsatte besøg af en medarbejder fra den russiske ambassade. Han skyndte sig at sige at jeg overhovedet ikke havde foretaget mig noget galt, men han ville advare mig. Russerne drev fortsat omfattende spionage i Danmark, men PETmanden ville særlig advare mig imod misinformation. Jeg sagde at alle møder havde foregået på mit kontor, og at jeg havde noteret dem alle sammen i min kalender. Dem for de sidste to år hentede jeg frem og viste ham. Han kendte til dem alle sammen undtagen ét.

Enten har min telefon eller ambassadens telefon været aflyttet. Gæt selv. Alle møder var telefonisk aftalt på forhånd. Og jeg fik ikke siden besøg af nogen Sergei. Hvem har udspioneret hvem? En efterretningstjeneste er i mine øjne utroligt vigtig fordi den også kan forebygge misforståelser. Man skal bare kunne stole på den. 


\section{Afsluttende uvidenskabelig efterskrift}

Jeg er ydmygt taknemlig for og stolt af at have fået lov at arbejde gennem så mange år for fremragende nordiske politikere og sammen med dygtige kolleger i en vigtig periode i de nordiske landes historie - en fredelig og meget konstruktiv periode med positive politiske brydninger. Tak for det.

Også en varm tak for gode råd og konstruktiv-kritisk gennemlæsning af teksten ved rådsdirektør Jan-Erik Enestam og fhv. informationschef Gitte Hemstra, og tak til min norske kollega Kjell MyhreJensen for hjælp med at fremskaffe billedet af fhv. statsminister Jan P. Syse og til bibliotekar Freddie Nielsen, Arbejdermuseet \& Arbejderbevægelsens Bibliotek og Arkiv, for hjælp med at fremskaffe billedet af fhv. statsminister Anker Jørgensen.

Af Henrik Hagemann, generalsekretær 1984-2009 for Danmarks Riges Delegation til Nordisk Råd.

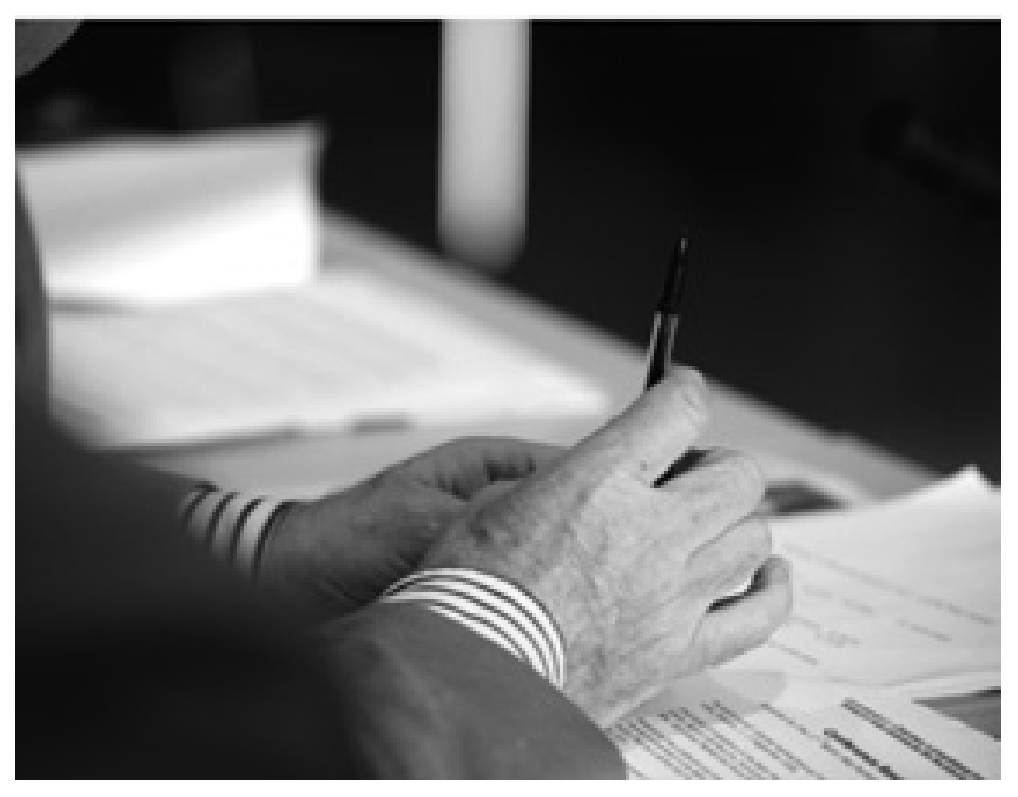



Baltic Sea Parliamentary Conference Secretariat www.bspc.net

c/o Nordisk Råd

Ved Stranden 18

1061 København K.

Telefon (+45) 33960400

www.norden.org.

US 2014:402

ISBN 978-92-893-2719-0

DOI http://dx.doi.org/10.6027/US2014-402 